\title{
PD-1 receptor on immune cells, its expres- sion and potential role in cancer therapy
}

\author{
Dmitry S. Elezov ${ }^{1}$, Igor V. Kudryavtsev ${ }^{2,3,4}$ \\ ${ }^{1}$ Raisa Gorbacheva Memorial Research Institute of Pediatric Oncology, Hematology and Transplantation, Pavlov First Saint \\ Petersburg State Medical University, St. Petersburg, Russia \\ ${ }^{2}$ Department of Immunology, Institute of Experimental Medicine, St. Petersburg, Russia \\ ${ }^{3}$ Department of Oncoimmunology, N. N. Petrov National Medical Research Center of Oncology, St. Petersburg, Russia \\ ${ }^{4}$ Department of Fundamental Medicine, Far Eastern Federal University, Vladivostok, Russia
}

Dr. Dmitry S. Elezov, PhD (Medicine), Raisa Gorbacheva Memorial Research Institute of Pediatric Oncology, Hematology and Transplantation, Pavlov First Saint Petersburg State Medical University, L. Tolstoy St 6-8, 197022,

St. Petersburg, Russia
Phone: +7 (953) 4104450

E-mail: elezovds@yahoo.com

Citation: Elezov DS, Kudryavtsev IV. PD-1 receptor on immune cells, its expression and potential role in cancer therapy. Cell Ther Transplant 2019; 8(2): 8-16.

\section{Summary}

PD-1 is among key receptors conveying an inhibitory signal to T cells. Over last decade, PD-1 and its ligand PD-L1 draw much attention, due to high efficiency of therapy with PD-1/PD-L1 inhibitors in a number of malignant disorders. In this review article, we aimed to summarize current data on the $\mathrm{PD}-1$ receptor expression in different immune cell subpopulations, like as its potential role in cellular antitumor response. Along with molecular structure and receptor-ligand interactions, the main attention is drawn to special features of PD-1 expression on the CD8+ T cell population which plays a key role in antitumor immune response. Some common changes of PD-1 expression levels during the cell activation and differentiation are considered, mainly, for the CD8+ T cells. Moreover, we discuss PD-1 expression on the surface of regulatory T cells, NK cells, invariant NKT cells, myeloid suppressor cells which may play an important role for anticancer immune response. When performing current therapy with $\mathrm{PD}-1 / \mathrm{PD}-\mathrm{L} 1$ inhibitors, the mentioned populations may influence development of resistance to this mode of immune treatment. Therefore, a number of recent studies are directed for studying the PD-1/PD-L1 involvement into the immune regulation and to test prospects of their usage as biomarkers for clinical immune checkpoint therapy.

\section{Keywords}

PD-1, PD-L1, expression, T cells, antitumor therapy, checkpoint inhibitors.

\section{Introduction}

Over last decade, the issue of PD-1 and PD-1 ligand (PD-L1) is being actively studied due to attempted clinical usage of their inhibitors in cancer treatment. In particular, PD-1 inhibitory drugs (e.g., nivolumab) have elicited good response in Hodgkin's disease patients [1] if also applied in the setting of hematopoietic stem cell transplantation (HSCT). Activation of antitumor $\mathrm{T}$ cell populations is considered the main reason for success in anti-PD-1 treatment. However, only a part of patients are responding to the PD-1 inhibitors, thus suggesting individual differences of $\mathrm{PD}-1 / \mathrm{PD}-\mathrm{L} 1$ regulation. These patient-specific differences should be better described at the levels of PD-1 production, PD-1/PD-L1 binding, and resulting stimulation of anticancer immunity in distinct clinical disorders. Hence, the immune regulation mechanisms of PD-1 and other immune checkpoint molecules are still poorly understood in many aspects. We tried to summarize the latest data on PD-1 receptor immunology and its potential role in the development of antitumor response. 
CD8+ T cells present the key effector population of antitumor adaptive immune response. A lot of positive and negative factors are known to participate in their regulation. At the present time, the so-called "double-signal" model is used to describe a TCR-mediated recognition by naïve T lymphocyte of $\mathrm{MHC} /$ antigen on antigen-presenting cell. This recognition event results either into activation of $\mathrm{T}$ cells, or its anergy.

To achieve effective activation of antigen-specific T lymphocytes, a signal from the TcR/MHC complex should be accomplished by additional antigen-independent (or costimulatory) signal from other receptors on the responding $\mathrm{T}$ cells. However, certain factors may down-regulate the $\mathrm{T}$ cell activation. These suppressive effects are performed via appropriate receptors on T cells (e.g. PD-L1 and PD-L2) functioning as immune checkpoints [2]. Under normal conditions, this inhibitory mechanism prevents excessive activation of T cell populations, e.g., adverse autoimmune reactions, thus maintaining a peripheral immune tolerance [3]. The opposite task, i.e., promotion of $\mathrm{T}$ cell-mediated antitumor activity requires inhibition of the $\mathrm{PD}-1$ receptors, performed by specific anti-PD-1 monoclonal antibodies now proposed for clinical use.

Hence, special attention is drawn to these costimulatory and coinhibitory interactions, since appropriate pathways are involved in immune escape of malignant tissues or virus-infected cells, as well as in development of autoimmune reactions [4]. The costimulatory and inhibitory receptors are not limited to naïve $\mathrm{T}$ cells, being also active in regulatory, effector and memory $\mathrm{T}$ cells. The most studied costimulatory pathway includes CD80(B7-1)/CD86(B7-2) receptors on the surface of antigen-presenting cells that interact with CD28 Ig-like molecules on T lymphocytes. There are both costimulatory receptors (CD28, ICOS), and inhibitory molecules (CTLA-4, PD-1, BTLA) on lymphocytes (Fig. 1).

ICOS-L MHC CD80/CD86 PD-L1/PD-L2 HVEM



Figure 1. Main molecules and interactions during T cell activation. CD28 family receptors and their ligands on the membranes of T lymphocytes (bottom) during their contacts with ligand molecules on the antigen-presenting cells (top)
PD-1 molecule is a member of CD28 family, but, like as its main ligand (PD-L1), it is considered a separate player at these signal pathways participating in T cell activation. Initial therapeutic interest was connected with an opportunity to augment the immune response via the costimulatory signal receptors. However, with discovery of immune checkpoints, the research was focused on these inhibitory molecules thus providing impressive results in therapy of some malignant diseases and a Nobel Prize 2018 for J. P. Allison (studies in PD-1/PD-L1) and T. Honjo (discovery of CTLA4 receptor). The both inhibitory receptors are involved into APC-T cell interactions (Fig. 2). The targeted CTLA-4 inhibition by Ipilimumab was initially used for antitumor immune therapy, proving its efficiency in melanoma and other epithelial carcinomas. Monoclonal antibodies to PD-L1 were developed later, and numerous clinical trials have shown its efficiency in some malignancies, especially, Hodgkin lymphoma and melanoma, thus giving some promise for usage of PD-1/ PD-L1 inhibitors in clinical oncology [5].

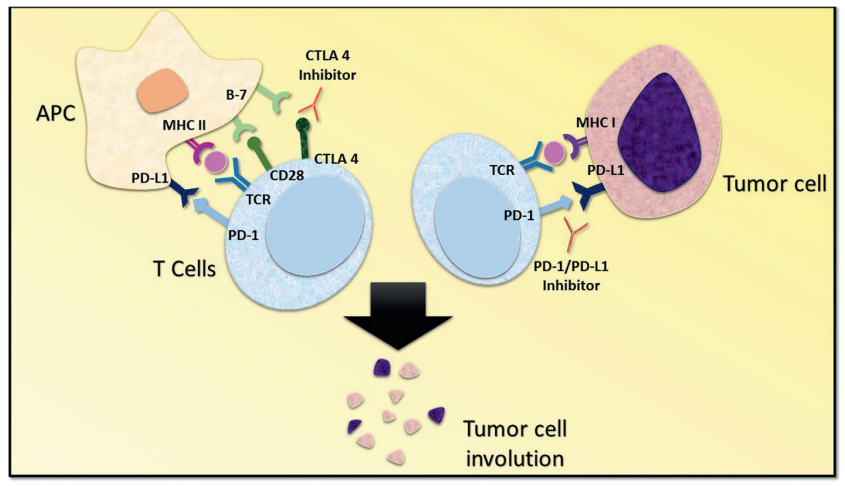

Figure 2. Mechanism of CTLA 4 and PD-1/PD-L1 inhibition. The activation of T cells is mediated by the interaction of T cell receptor and the CD28 receptor with class II major histocompatibility complex and B7 costimulatory molecule. The interaction of CTLA-4 with B7 molecule delivers an inhibitory signal, effectively checked by CTLA-4 inhibitors. The negative regulation of T cells resulting from PD-1/PD-L1 interaction between T cells and tumor cells is prevented by PD-1/PD-L1 inhibitors (Chae et al., 2018) [5]

\section{PD-1: molecular structure}

The Programmed Death-1 receptor (PD-1, CD279) is expressed on the surface membrane of some immune cell populations. As many other membrane receptors, $\mathrm{PD}-1$ is a transmembrane protein (type 1) from the immunoglobulin superfamily, with extracellular IgV domain. PD-1 is broadly represented on different leukocyte populations and it can be detected on T, B, NK, and natural killer T cells (NKT cells), as well as on monocytes, dendritic cells, thymocytes. The protein consists of 288 amino acids and includes an Ig-variable domain, a "stem" of ca. 20 amino acids, as well as transmembrane and cytoplasmic domains. The latter includes tyrosine-based inhibitory signal motifs (ITIM), a similar tyrosine-based switch motif (ITSM). PD-1 is encoded by the $P d c d 1$ gene mapped at the chromosome 2 in humans 
(in mice, at chromosome 1). $P d c d 1$ contains 5 protein-coding exons, i.e.: exon 1 encodes signal sequence; exon 2 for the $\mathrm{IgV}$ domain; exon3, for transmembrane domain; exons 4 and 5 encode cytoplasmic domain with ITIM- and ITSM motifs. Four additional protein variants may exist, due to alternative mRNA splicing. The soluble PD-1 form is encoded by the $P d c d 1$ variant with missed exon 3 [6]. The $P d c d 1$ transcription is regulated by several transcription factors, i.e., NFATc1 [7], IRF9 [8], FoxO1 [9], Notch signaling [10]. T-bet and Blimp-1 factors are known to inhibit PD-1 expression $[11,12]$.

\section{PD-1 ligands: PD-L1 and PD-L2}

PD-1 is able to bind some specific ligands, i.e., PD-L1 (B7H1, CD274), or PD-L2 (B7-DC, CD273). These inhibitory molecules are necessary for induction of immunological tolerance and suppression of excessive tissue damage in the inflammatory foci in peripheral tissues, and, probably, escape of tumor cells from immune surveillance. Affinity of PD-L2 for PD-1 is 2 to 6-fold higher than PD-L1/PD-1 binding [13]. However, most studies deal with PD1/PDL1 interactions that are primarily caused by broad PD-1 distribution and ability of its expression on various hematopoietic cells and other tissues. On the contrary, PD-L2 expression is mostly limited by dendritic cells, macrophages and lung cells. PD-1 ligands exhibit additional receptors. PD-L1 interacts with B7-1 (CD80) and participates in transduction of inhibitory signal [14]. Hence, B7-1 represents a common ligand for the three receptor types: CD28, CTLA-4, PD-L1 (Fig. 3). Moreover, PD-L2 may bind the RGMB (Repulsive Guidance Molecule B) expressed on lung macrophages, and on alveolar epithelium, thus participating in maintenance of local immune tolerance [15].

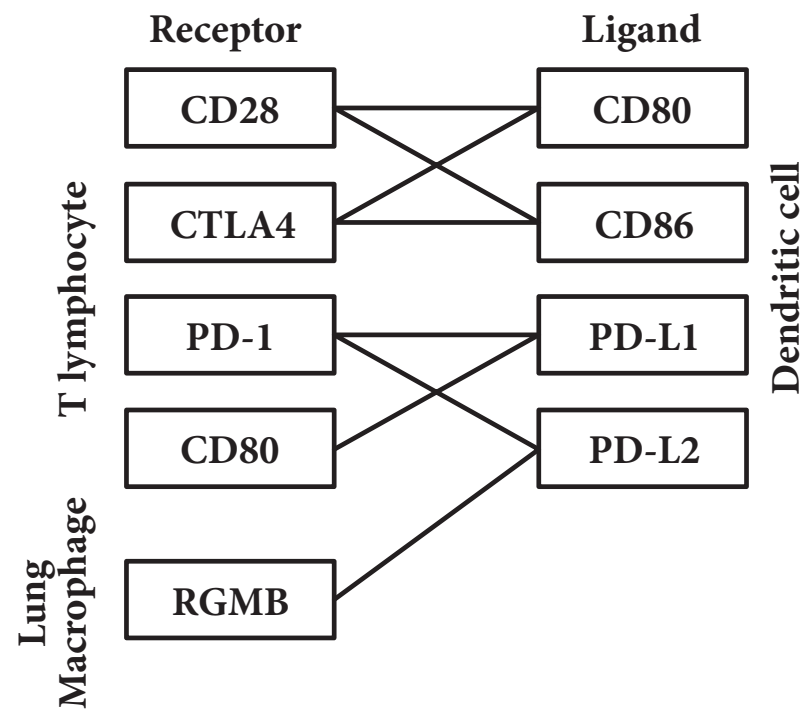

Figure 3. Main molecular interactions connected with PD-1 pathway

\section{Methodology of PD-1/PD-L1 detection in tumor samples}

There are some conventional laboratory methods of PD-1/ PDL-1 diagnostics and appropriate semi-quantitative assays based on detection of specific protein or mRNAs. Immunohistochemical (IHC) testing has some problems with different quality of biopsies as well with cutoff values. Despite of these issues, several IHS commercial systems are now used and intercompared. Moreover, detection of soluble PD-L1 (sPD-L1) is feasible in blood sera of the patients with solid cancer, showing some correlation with response to PD-1 inhibitors [16].

In general, however, the $\mathrm{PD}-1$ receptors and their ligands in tissue samples are detected by immunohistochemical techniques at single-cell level, as it was performed by Zaya et al. [17]. The workers studied expression of PD-1/PD-1L in different specimens of malignant tissue from the patients with nodal peripheral T-cell lymphomas. The slices from formalin-fixed paraffin-embedded blocks were used for immunostaining, and the ratios of antigen-positive cells were scored at 0 to 4 . Their quite heterogenous results for different lymphoma types have shown great complexity of PD-1/PDL1 expression which, probably, may impact on clinical response to PD-1 and PD-1L inhibitors.

To study systemic malignancies (e.g., leukemias), or to assess leukocyte populations, flow cytometric methods may be applied as it was performed by Zhang et al. [18]. The authors studied PD-1 expression on the surface of CD4+, CD8+ lymphocytes and PDL-1 on the monocytes of cervical cancer patients. Such approach may be also applied to the patients with myelo- and lymphoproliferative disorders in case of appropriate trials with PD-1 inhibitors.

FISH techniques allow of determining PDL-1 gene copy numbers in malignant cells, i.e. specific gene amplification in the cells of interest. As shown with lung cancer specimens, this parameter seems to correlate with PDL-1 protein expression, as well as overall survival of the patients [19].

\section{PD-1 expression and functioning of T cells}

PD-1 is an antagonist of signals coming from the T cell receptor. Therefore, its expression research has aroused great practical interest. PD-1 expression on $\mathrm{T}$ cells is a consequence of cell activation, showing a distinct kinetics. Along with TcR/antigen contact, it may be induced by cytokines with common $\gamma$-chain, e.g., IL-2, IL-7, IL-15 [20], IFNa [8], and, to lesser degree, with IL-21.

PD-1 is absent or low on the surface of resting T cells. However, its expression levels are drastically increasing within several hours after stimulation [21]. E.g., the PD-1 levels on $\mathrm{T}$ helpers from peripheral blood showed a four-fold increase as soon as $24 \mathrm{~h}$ after their in vitro exposure to standard cell stimulants (PMA or ionomycin) [22]. Experiments with in vitro activation of murine lymph node lymphocytes 
have shown PD-1 expression detectable in 1/3 of the CD4+ и CD8+ cells having been activated for 24 hours [23]. PD-1 expression level in $\mathrm{T}$ and $\mathrm{B}$ cells from mouse spleen was also increased following stimulation with anti-CD3 antibodies, or ConA and anti-IgM antibodies [24]. Differential effects are shown for distinct agents, e.g., bacterial LPS or dexamethasone did not affect PD-1 levels, whereas PMA/ionomycin caused an increase of this receptor on the surface of murine $\mathrm{T}$ and $\mathrm{B}$ lymphocytes. Hence, the inhibitory effects of PD-1 may be exhibited as soon as upon their early activation.

When studying the inhibitory effects of PD-1 upon T cell functions, an association was revealed between the rate of signal, resulting from the ligand-receptor interactions, and ability of cells for cytokine production, proliferation and cytotoxic activities in response to antigenic stimulation [25]. E.g., the PD-1 stimulation did not exert sufficient effects upon IFN $\gamma$ and $\beta$-chemokine production, associated with full inhibition of IL-2 and TNFa secretion.

Meanwhile, the cytotoxic T cells that expressed PD-1 at very high rates, were able to trigger a reaction cascade switching the in vitro apoptosis [26]. Introduction of antibodies to PD-1 into the cell cultures promoted apoptosis only in the cell populations with $\mathrm{PD}-1^{\text {high }}++\mathrm{CD} 3+\mathrm{CD} 8+$ phenotype, without any sufficient effect upon cytotoxic T cells expressing PD-1 at low density.

A similar trend was noted for the virus-specific $\mathrm{T}$ cells, when the PD-1/PD ligand interaction was followed by apoptosis, but not effector attack towards virus-infected cells. When studying chronic virus choriomeningitis in mice, blockage of PD-1/PD-L1 pathway during early activation of naive $\mathrm{T}$ cells resulted into stronger effects of cytotoxic T cells against the virus-infected cells [27]. Exponential clonal T cell expansion was also observed, with TcR re-expression within 2 weeks and accumulation of antigen-specific cells able to express cytotoxic properties. [28]. In case of PD-L1 pathway blockade, a population of hyperactivated proinflammatory TCR ${ }^{\text {high }} \mathrm{CD} 8+\mathrm{T}$ cells, able to exhibit and augment antitumor immune response along with probable autoimmune lesions in the model of mice lymphoma [28, 29].

\section{PD-1 expression on T cells depends on their differentiation state}

Normally, PD-1 is detected on ca. $10 \%$ of peripheral T cells, with similar rates for CD4+ and CD8+ T lymphocytes [30]. PD-1 expression levels sufficiently differ at distinct stages of $\mathrm{T}$ cell differentiation and besides show some special features for the high- and low-PD1 populations. E.g., when assaying PD-1 expression on peripheral cytotoxic T cells from healthy donors, this receptor was revealed on $40-80 \%$ memory $\mathrm{T}$ cells, being absent on naïve cells [31,32]. Among mature cytotoxic cells, PD-1 was revealed on $60 \%$ of the memory effector cells with CD45RA-CCR7-, whereas this value did not exceed $25 \%$ for the central memory cells. Higher expression of mRNAs for CD28 and CD27 costimulators and inhibitory CTLA-4 receptors, as well as homing-mediating chemokine receptors CXCR6, CXCR4 и CCR5, and Granzyme $\mathrm{K}$ were characteristic for the PD-1hi cells. If compared with PD-1-negative cytotoxic T cells, the low KIR «killer cell Ig-like receptors» expression, as well as low Granulysin and Granzyme B expression were revealed in the given population. Notably, presence of PD-1 on the cell surface was associated with decreased levels of mRNAs for cell adhesion molecules, i.e., CD11b, CD11c and CD56 [31].

Surface phenotypic analysis of PD-1 $1^{\text {hi }}$ and PD-1 $1^{\text {low }}$ CD8+ memory $\mathrm{T}$ cell populations has shown that CD127 expression is higher at the PD- $1^{\text {hi }}$ cell surface whereas more perforin was revealed in the granules of PD- $1^{\text {low }}$ cells. Moreover, the PD-1 positivity was accompanied by increased CD95/Fas levels and decreased anti-apoptotic factor Bcl-2, if compared to the PD-1-negative cells [33].

Worth of note, the PD-1 expression is sometimes used as an additional marker of $\mathrm{T}$ cell differentiation. E.g., the phenotype of central memory $\mathrm{T}$ cells could be described as CCR7+CD27+CD28+CD45RA-CD57-KLRG1-PD1- cells. In the course of further differentiation into the effector memory cells, they acquire CCR7-CD27+/-CD28+/-CD45RACD57+/-KLRG1+/-PD1+ profile, whereas differentiated TEMRA effector cells are described as CCR7-CD27-CD28CD45RA+CD57+KLRG1+PD1+/- subpopulation [34]. This approach allows to consider PD-1, along with CD57 and KLRG1, as markers of late differentiation $\mathrm{T}$ lymphocyte aging.

\section{PD-1 expression in different subpopulations of immune cells}

\section{Regulatory $\mathrm{T}$ cells}

The PD-1/PD-L1 interactions are highly important for differentiation of naïve $\mathrm{T}$ cells towards induced regulatory cells (iTregs) and for their functional support $[35,36]$. E.g., the TGF $\beta$-mediated transition from naïve $T$ cells to Tregs proceeded much more efficient in contact with PD-L1 than in absence of this ligand. Also it was shown for Th1 polarization towards Tregs [37]. Moreover, the contacts between PD-1 on regulatory $\mathrm{T}$ cells and $\mathrm{PD}-\mathrm{L} 1$ on cytotoxic $\mathrm{T}$ cells are quite necessary for suppressory effect of CD8+ T cells, as shown for the virus-specific immune response [38]. After blockade of PD-1, but not PD-L1 separately on murine Treg cells in vitro, a decreased suppressor activity of this population was observed with respect to cytotoxic $\mathrm{T}$ cell proliferation and IFN $\gamma$ production. Such features of $\mathrm{PD}-1 / \mathrm{PD}-\mathrm{L} 1$ signaling towards Tregs may be considered as a special mechanism causing insufficiency of, e.g., antitumor immune response, in case of excessive PD-L1 production by malignant cells [39].

\section{NK cells}

PD-1 expression shows some specific features in natural killer (NK) cell populations. When studying CMV-seropositive donors and patients with ovarian cancer, the $\mathrm{PD}-1$ receptor was highly expressed on CD56 ${ }^{\text {dim }}$, but not on CD56 $6^{\text {bright }}$ blood lymphocytes with mature NK phenotype (NKG2A$\mathrm{KIR}+\mathrm{CD} 57+$ ) [39]. The PD-1-specific mRNA expression was also higher in CD56 $6^{\mathrm{dim}}$ than in CD56 $6^{\text {bright }} \mathrm{NK}$ cells, and the specific protein was detected in all NK cells by means of confocal microscopy [41]. PD-1 expression on NK cells was also shown in other cancers, e.g. Kaposi sarcoma myeloma 
and gastrointestinal cancers [42, 43, 44]. Studying the effects of PD-1/PD-L1 blockage in various in vitro systems and murine cancer models has demonstrated a significance of this signal pathway for inhibition of NK cell functions, as well as their recovery in case of its blockade [45, 46]. However, real significance of the PD1/PDL1 pathway in antitumor immune response, and in particular, antitumor activity against malignant cells with acquired MHC-1 loss is not clear so far. Therefore, the NK activation mechanisms when using PD-1/ PD-L1 inhibitors remain unclear and deserve further studies. E.g., one may suggest induced PD-L1 expression by tumor cells in response to IFN $\gamma$ secretion by NK cell, with subsequent attraction of PD-1+ T cells and Tregs expansion [46].

\section{Invariant NKT cells (iNKT)}

PD-1/PD-L1 signaling is important for invariant NKT cells both in cancer and chronic viral diseases. E.g., peripheral iNKT cells in patients with non-small-cell lung cancer expressed PD-1 at sufficiently higher levels than in healthy donors [47]. In vitro stimulation of iNKT cells by a-galactosyl ceramide caused increased PD-1 expression, whereas PD-1/ PD-L1 blockage prevented anergy of this population and induced Th1-cytokines, thus leading to NK cell activation [47, $48,49]$.

\section{Myeloid suppressor cells (MDSC)}

MDSC population is able to inhibit T and NK cell activity, thus being considered as a suppressor population. The MDSC level and PD-1 expression are increased under permanent antigenic stimulation. E.g., the patients with chronic hepatitis B exhibited higher levels of MDSC (CD14+HLA-DR- ${ }^{\text {low }}$ ) in peripheral blood, as well as PD-1 expression on these cells. The suppressor effects of this population against cytotoxic $\mathrm{T}$ cells could be caused by the PD-1-induced IL-10 production [50]. In mice with mammary tumors, a largely increased PD-1 expression was revealed in tumor-infiltrating MDSCs $(\mathrm{CD} 11 \mathrm{~b}+\mathrm{Gr} 1+)$, when compared to expression in bone marrow and spleen. Moreover, the PD-1+ MDSC population showed higher proliferation rates than the $\mathrm{PD}$-1-negative MDSCs [51]. MDSCs may influence the efficiency of anticancer immune therapy with PD-1/PD-L1 inhibitors [52], and contents of this population may be regarded as a potential prognostic marker in this treatment mode [53].

\section{PD-1 expression on T cells in malignant diseases}

The inhibitors of PD-1/PD-L1 have yielded impressive results in clinics when treating several cancer diseases, despite still unclear immunological effects produced by these agents. However, efficiency of such therapeutic option proved to be maximal in cancer with high mutation burden, or in tumors with very high expression of PD-L1. In general, the rate of PD-L1 expression in tumors is limited to 20 per cent of cases, but the therapeutic effects are not limited by only absence or presence of PD-L1 or PD-1 expression on malignant cells or tumor-associated lymphocytes [54]. In recent years, clinical research is directed towards combined anticancer therapy including PD-1/PD-L1 inhibitors, in order to improve clinical outcomes [55].
PD-L1, a natural PD-1 ligand, was subject to a number of studies in the field of cancer therapy. PD-L1 expression is normally absent in benign tissues, but it is observed in malignant cells. Increased PD-L1 expression seems to be induced by IFN $\gamma$, a physiological response limiting the inflammation area and preventing tissue damage $[56,57]$. Cancer cells and their microenvironment may develop PD-L1 expression, due to attraction of lymphocytes, i.e., IFN $\gamma$-producing $\mathrm{T}$ cells. In melanoma patients, the melanocytes are grouped around PD-1+ tumor-infiltrating lymphocytes [58]. The T cells expressing PD-1 (and, probably, B7-1) seem to become dysfunctional when binding PD-L1, and they lose their effector abilities, thus leading to escape of tumor cells from immune surveillance, causing the so-called adaptive resistance [59].

Current predictive diagnostics of the PD-1/PD-L1 blocker efficiency is based on this presumption, by determining PDL1 expression in malignant tissue by means of immunohistochemistry. More recently, a number of works suggest low efficiency of this index as a marker of therapeutic response [60]. Moreover, a constitutively high PD-L1 expression is found in some cancers which does not depend on presence of tumor-infiltrating lymphocytes, e.g., in Hodgkin lymphoma $[61,62]$. Hence, the patients with PD-L1 negative tumors can still respond to immune checkpoint blockade, however a subgroup of PD-L1+ patients still do not respond, as shown for some common solid cancers [63].

PD-1 expression is increased on the surface of T cells in the wide range of oncological diseases [64, 65]. Expression of this molecule in melanoma was sufficiently higher on the tumor-infiltrating CD4+ and CD8+ T cells as compared to normal blood cells and tissues. Antigen-specific T cells showed the same feature. PD1-positive intratumor CD8+ $\mathrm{T}$ cells were characterized by the so-called "exhausted" phenotype: they expressed CTLA-4, showed low cytokine production in response to PMA/ionomycin, but being mostly positive for HLA-DR and CD127-negative [65].

In breast cancer, PD-1 expression in tumor-infiltrating CD8+ T cells was also increased. However, the intratumor T cells had different phenotype and functional properties, i.e, TIM-3 and 2B4 proved to be more expressed on CD8+ T cells from melanoma patients, whereas CD8+ T cells from breast cancer patients retained their degranulation ability, IFN $\gamma$, TNFa and IL-2 production, and could be therefore regarded as functional cell population [66]. Similar situation is noted for other malignant diseases including oncohematological diseases, e.g AML [67]. Hence, an increased PD-1-expression on CD8+ T cells could not be considered a common feature of cellular dysfunction which may develop in response to a variety of microenvironmental factors in distinct tumor types.

Hence, PD-1 expression in T lymphocytes, being induced by many biologically active factors, is the least reliable predictor of clinical response to PD-1 inhibitors. So far, the major predictive markers for checkpoint inhibitor response include PD-L1 expression, and indirect markers, such as high tumor mutational burden, microsatellite instability, CD8 infiltrates etc. [63]. 


\section{Conclusion}

PD-1 is an inhibitory receptor of cellular immune response expressed on different immune cell populations. There are sufficient features of PD-1 expression and regulation of antitumor response, being dependent on PD-1 ligands (PDL-1), costimulatory molecules and target tumor antigens.

We have considered some features of PD-1 expression in normal cells and malignancies which show great variability when studied in experimental models and under clinical conditions. This functional heterogeneity may explain wide variability of individual response in clinical studies of PD-1 inhibitors in different human malignancies. Further search for more reliable and immediate laboratory predictors of response to PD-1 inhibitors deserve future studies.

\section{Conflict of interest}

No conflict of interests is declared.

\section{References}

1. Lepik KV, Kozlov AV, Borzenkova ES, Popova MO, Moiseev IS, Darskaya EI, Gevorgyan AG, Tsvetkova LA, Bondarenko SN, Alyanskiy AL, Kondakova EV, Mikhailova NB, Afanasyev BV. Safety and efficacy of nivolumab applied at different dosage in the patients with relapsing Hodgkin lymphoma after allogeneic hematopoietic stem cell transplantation. Cell Ther Transplant; 7(2):28-35.

2. Pardoll DM. The blockade of immune checkpoints in cancer immunotherapy. Nat Rev Cancer. 2012; 12(4):252264.

3. Sharpe AH, Pauken KE. The diverse functions of the PD1 inhibitory pathway. Nature reviews. Immunology. 20; 1818:153-167.

4. Bucktrout SL, Bluestone JA, Ramsdell F. Recent advances in immunotherapies: from infection and autoimmunity, to cancer, and back again. Genome Med. 2018; 10(1):79.

5. Chae YK, Arya A, Iams W, Cruz MR, Chandra S, Choi J, Giles F. Current landscape and future of dual antiCTLA4 and PD-1/PD-L1 blockade immunotherapy in cancer: lessons learned from clinical trials with melanoma and non-small cell lung cancer (NSCLC). J Immuno Ther Cancer. $2018 ; 6: 39$

6. Nielsen C, Ohm-Laursen L, Barington T, Husby S, Lillevang ST. Alternative splice variants of the human PD-1 gene. Cell Immunol. 2005; 235(2):109-116.

7. Oestreich KJ, Yoon H, Ahmed R, Boss JM. NFATc1 regulates PD-1 expression upon T cell activation. J Immunol. 2008; 181:4832-4839.

8. Terawaki S, Chikuma S, Shibayama S, Hayashi T, Okazaki T, Honjo T. IFN- $\alpha$ directly promotes programmed cell death- 1 transcription and limits the duration of T cell-mediated immunity. J Immunol. 2011; 186:2772-2779.

9. Staron MM, Gray SM, Marshall HD, Parish IA, Chen JH, Perry CJ, Cui G, Li MO, Kaech SM. The transcription factor FoxO1 sustains expression of the inhibitory receptor PD-1 and survival of antiviral CD8(+) T cells during chronic infection. Immunity. 2014; 41:802-814.
10. Mathieu M, Cotta-Grand N, Daudelin JF, Thebault P, Labrecque N. Notch signaling regulates PD-1 expression during CD8(+) T-cell activation. Immunol Cell Biol. 2013; 91:82-88

11. Kao C, Oestreich KJ, Paley MA, Crawford A, Angelosanto JM, Ali MA, Intlekofer AM, Boss JM, Reiner SL, Weinmann AS, Wherry EJ. Transcription factor T-bet represses expression of the inhibitory receptor PD-1 and sustains virus-specific CD8+ T cell responses during chronic infection. Nat Immunol. 2011; 12:663-671.

12. Lu P, Youngblood BA, Austin JW, Mohammed AU, Butler R, Ahmed R, Boss JM. Blimp-1 represses CD8 T cell expression of PD-1 using a feed-forward transcriptional circuit during acute viral infection. J Exp Med. 2014; 211(3):515527.

13. Youngnak P, Kozono Y, Kozono H, Iwai H, Otsuki N, Jin H, Omura K, Yagita H, Pardoll DM, Chen L, Azuma M. Differential binding properties of B7-H1 and B7-DC to programmed death-1. Biochem Biophys Res Commun. 2003; 307(3):672-677.

14. Butte MJ, Keir ME, Phamduy TB, Sharpe AH, Freeman GJ. Programmed death-1 ligand 1 interacts specifically with the B7-1 costimulatory molecule to inhibit T cell responses. Immunity. 2007; 27:111-122.

15. Xiao Y, Yu S, Zhu B, Bedoret D, Bu X, Francisco LM, Hua P, Duke-Cohan JS, Umetsu DT, Sharpe AH, DeKruyff RH, Freeman GJ. RGMb is a novel binding partner for PD-L2 and its engagement with PD-L2 promotes respiratory tolerance. J Exp Med. 2014; 211:943-959.

16. Okuma Y, Hosomi Y, Nakahara Y, Watanabe K, Sagawa Y, Homma S. High plasma levels of soluble programmed cell death ligand 1 are prognostic for reduced survival in advanced lung cancer. Lung Cancer. 2017;104:1-6. doi: 10.1016/j.lungcan.2016.11.023.

17. Zaja F, Tabanelli V, Agostinelli C, Calleri A, Chiappella A, Varettoni M, Luigi Zinzani P, Volpetti S, Sabattini E, Fanin R, Pileri SA. CD38, BCL-2, PD-1, and PD-1L expression in nodal peripheral T-cell lymphoma: Possible biomarkers for novel targeted therapies? Am J Hematol. 2017; 92(1):E1-E2. doi: 10.1002/ajh.24571.

18. Zhang Y, Zhu W, Zhang X, Qu Q, Zhang L Expression and clinical significance of programmed death-1 on lymphocytes and programmed death ligand-1 on monocytes in the peripheral blood of patients with cervical cancer. Oncol Lett. 2017;14(6):7225-7231. doi: 10.3892/ol.2017.7105.

19. Inoue Y, Yoshimura K, Mori K, Kurabe N, Kahyo T, Mori H, Kawase A, Tanahashi M, Ogawa H, Inui N, Funai K, Shinmura K, Niwa H, Suda T, Sugimura H.Clinical significance of PD-L1 and PD-L2 copy number gains in non-small-cell lung cancer. Oncotarget. 2016;7(22):32113-1228. doi: 10.18632/ oncotarget.8528.

20. Kinter AL, Godbout EJ, McNally JP, Sereti I, Roby GA, O'Shea MA, Faici AS. The common gamma-chain cytokines IL-2, IL-7, IL-15, and IL-21 induce the expression of programmed death-1 and its ligands. J Immunol. 2008; 181:6738-6746. 
21. Chemnitz JM, Parry RV, Nichols KE, June CH, Riley JL. SHP-1 and SHP-2 associate with immunoreceptor tyrosine-based switch motif of programmed death 1 upon primary human $\mathrm{T}$ cell stimulation, but only receptor ligation prevents T cell activation. J Immunol. 2004; 173(2):945-954.

22. Sim JH, Park MJ, Park S, Lee ES. Altered expression of costimulatory molecules in Behçet's disease according to clinical activity. Br J Dermatol. 2011; 164(6):1285-1291.

23. Carter L, Fouser LA, Jussif J, Fitz L, Deng B, Wood CR, Collins M, Honjo T, Freeman GJ, Carreno BM. PD-1:PD-L inhibitory pathway affects both CD4(+) and CD8(+) T cells and is overcome by IL-2. Eur J Immunol. 2002; 32(3):634643.

24. Agata Y, Kawasaki A, Nishimura H, Ishida Y, Tsubata T, Yagita H, Honjo T. Expression of the PD-1 antigen on the surface of stimulated mouse $\mathrm{T}$ and B lymphocytes. Int Immunol. 1996; 8(5):765-772.

25. Wei F, Zhong S, Ma Z, Kong H, Medvec A, Ahmed R, Freeman GJ, Krogsgaard M, Riley JL Strength of PD-1 signaling differentially affects T-cell effector functions. PNAS. 2013; 110(27):2480-2489.

26. Petrovas C, Casazza JP, Brenchley JM, Price DA, Gostick E, Adams WC, Precopio ML, Schacker T, Roederer M, Douek DC, Koup RA. PD-1 is a regulator of virus-specific CD8+ T cell survival in HIV infection. J Exp Med. 2006; 203(10):2281-2292.

27. Ahn E, Araki K, Hashimoto M, Li W, Riley JL, Cheung J, Sharpe AH., Freeman GJ, Irving BA, Ahmed R. Role of PD-1 during effector CD8 T cell differentiation. PNAS. 2018; 115(18):4749-4754.

28. Karwacz K, Bricogne C, MacDonald D, Arce F, Bennett CL, Collins M, Escors D. PD-L1 co-stimulation contributes to ligand-induced $\mathrm{T}$ cell receptor down-modulation on CD8+ T cells. EMBO Mol Med. 2011; 3(10):581-592.

29. Arasanz H, Gato-Canas M, Zuazo M, Ibanez-Vea M, Breckpot K, Kochan G, Escors D. PD1 signal transduction pathways in T cells. Oncotarget. 2017; 8(31):51936-51945.

30. Zhang JY, Zhang Z, Wang X, Fu JL, Yao J, Jiao Y, Chen L, Zhang H, Wei J, Jin L, Shi M, Gao GF, Wu H, Wang FS. PD-1 up-regulation is correlated with HIV-specific memory CD8+ T-cell exhaustion in typical progressors but not in long-term nonprogressors. Blood. 2007; 109(11):4671-4678.

31. Duraiswamy J, Ibegbu CC, Masopust D, Miller JD, Araki K, Doho GH, Tata P, Gupta S, Zilliox MJ, Nakaya HI, Pulendran B, Haining WN, Freeman GJ, Ahmed R. Phenotype, function, and gene expression profiles of programmed death-1(hi) CD8 T cells in healthy human adults. J Immunol. 2011; 186(7):4200-4212.

32. Kudryavtsev IV, Borisov AG, Vasilyeva EV, Krobinets II, Savchenko AA, Serebriakova MK, Totolian AA. Phenotypic characterization of peripheral blood cytotoxic T lymphocytes: regulatory and effector molecules. Medical Immunology. 2018; 20(2):227-240 (in Russian).
33. Petrovas C, Chaon B, Ambrozak DR, Price DA, Melenhorst JJ, Hill BJ, Geldmacher C, Casazza JP, Chattopadhyay PK, Roederer M, Douek DC, Mueller YM, Jacobson JM, Kulkarni V, Felber BK et al. Differential association of programmed death-1 and CD57 with ex vivo survival of CD8+ T cells in HIV infection. J Immunol. 2009; 183(2):1120-1132.

34. Larbi A, Fulop T. From "truly naïve" to "exhausted senescent" T cells: when markers predict functionality. Cytometry A. 2014; 85(1):25-35.

35. Gotot J, Gottschalk C, Leopold S, Knolle PA, Yagita H, Kurts C, Ludwig-Portugall I. Regulatory T cells use programmed death 1 ligands to directly suppress autoreactive $\mathrm{B}$ cells in vivo. PNAS. 2012; 109(26):10468-10473.

36. Francisco LM, Salinas VH, Brown KE, Vanguri VK, Freeman GJ, Kuchroo VK, Sharpe AH. PD-L1 regulates the development, maintenance, and function of induced regulatory T cells. J Exp Med. 2009; 206(13):3015-3029.

37. Amarnath S, Mangus CW, Wang JC, Wei F, He A, Kapoor V, Foley JE, Massey PR, Felizardo TC, Riley JL, Levine $\mathrm{BL}$, June $\mathrm{CH}$, Medin JA, Fowler DH. The PDL1-PD1 axis converts human TH1 cells into regulatory T cells. Sci Transl Med. 2011; 3(111):111ra120.

38. Park HJ, Park JS, Jeong YH, Son J, Ban YH, Lee BH, Chen L, Chang G, Chung DH, Choi I, Ha SJ. PD-1 upregulated on regulatory $\mathrm{T}$ cells during chronic virus infection enhances the suppression of CD8+ T cell immune response via the interaction with PD-L1 expressed on CD8+ T cells. J Immunol. 2015; 194:5801-5811.

39. Penaloza-MacMaster P, Kamphorst AO, Wieland A, Araki K, Iyer SS, West EE, O'Mara L, Yang S, Konieczny BT, Sharpe AH, Freeman GJ, Rudensky AY, Ahmed R. Interplay between regulatory $\mathrm{T}$ cells and $\mathrm{PD}-1$ in modulating $\mathrm{T}$ cell exhaustion and viral control during chronic LCMV infection. J Exp Med. 2014; 211(9):1905-1918.

40. Pesce S, Greppi M, Tabellini G, Rampinelli F, Parolini S, Olive D, Moretta L, Moretta A, Marcenaro E. Identification of a subset of human natural killer cells expressing high levels of programmed death 1: a phenotypic and functional characterization. J Allergy Clin Immunol. 2017; 139(1) :335-346.

41. Mariotti FR, Petrini S, Ingegnere T, Tumino N, Besi F, Scordamaglia F, Munari E, Pesce S, Marcenaro E, Moretta A, Vacca P, Moretta L. PD-1 in human NK cells: evidence of cytoplasmic mRNA and protein expression. Oncoimmunology. 2019; 8(3):1557030.

42. Beldi-Ferchiou A, Lambert M, Dogniaux S, Vely F, Vivier E, Olive D, Dupuy S, Levasseur F, Zucman D, Lebbe C, Sene D, Hivroz C, Caillat-Zucman S. PD-1 mediates functional exhaustion of activated NK cells in patients with Kaposi sarcoma. Oncotarget. 2016; 7(45):72961-72977.

43. Benson DM, Bakan CE, Mishra A, Hofmeister CC, Efebera Y, Becknell B, Baiocchi RA, Zhang J, Yu J, Smith MK, Greenfield CN, Porcu P, Devine SM, Rotem-Yehudar R, Lozanski G, Byrd JC, Caligiuri MA. The PD-1/PD-L1 axis modulates the natural killer cell versus multiple myeloma effect: a therapeutic target for CT-011, a novel monoclonal anti-PD-1 antibody. Blood. 2010; 116(13):2286-2294. 
44. Liu Y, Cheng Y, Xu Y, Wang Z, Du X, Li C, Peng J, Gao L, Liang X, Ma C. Increased expression of programmed cell death protein 1 on NK cells inhibits NK-cell-mediated anti-tumor function and indicates poor prognosis in digestive cancers. Oncogene. 2017; 36(44):6143-6153.

45. Hsu J, Hodgins JJ, Marathe M, Nicolai CJ, Bourgeois-Daigneault MC, Trevino TN, Azimi CS, Scheer AK, Randolph HE, Thompson TW, Zhang L, Iannello A, Mathur N, Jardine KE, Kirn GA, Bell JC, McBurney MW, Raulet $\mathrm{DH}$, Ardolino M. Contribution of NK cells to immunotherapy mediated by PD-1/PD-L1 blockade. J Clin Invest. 2018; 128(10):4654-4668.

46. Oyer JL, Gitto SB, Altomare DA, Copik AJ. PD-L1 blockade enhances anti-tumor efficacy of NK cells. Oncoimmunology. 2018; 7(11):e1509819.

47. Kamata T, Suzuki A, Mise N, Ihara F, Takami M, Makita Y, Horinaka A, Harada K, Kunii N, Yoshida S, Yoshino I, Nakayama T, Motohashi S. Blockade of programmed death-1/ programmed death ligand pathway enhances the antitumor immunity of human invariant natural killer T cells. Cancer Immunol Immunother. 2016; 65(12):1477-1489.

48. Chang WS, Kim JY, Kim YJ, Kim YS, Lee JM, Azuma M, Yagita H, Kang CY. Cutting edge: Programmed death-1/programmed death ligand 1 interaction regulates the induction and maintenance of invariant NKT cell anergy. J Immunol. 2008; 181:6707-6710.

49. Parekh VV, Lalani S, Kim S, Halder R, Azuma M, Yagita H, Kumar V, Wu L, Kaer LV. PD-1/PD-L blockade prevents anergy induction and enhances the anti-tumor activities of glycolipid-activated invariant NKT cells. J Immunol. 2009; 182:2816-2826.

50. Huang A, Zhang B, Yan W, Wang B, Wei H, Zhang F, Wu L, Fan K, Guo Y. Myeloid-derived suppressor cells regulate immune response in patients with chronic hepatitis $\mathrm{B}$ virus infection through PD-1-induced IL-10. J Immunol. 2014; 193:5461-5469.

51. Nam S, Lee A, Lim J, Lim JS. Analysis of the Expression and Regulation of PD-1 Protein on the Surface of Myeloid-Derived Suppressor Cells (MDSCs). Biomol Ther. 2019; 27(1):63-70.

52. Weber R, Fleming V, Hu X, Nagibin V, Groth C, Altevogt P, Utikal J, Umansky V. Myeloid-Derived Suppressor Cells Hinder the Anti-Cancer Activity of Immune Checkpoint Inhibitors. Front Immunol. 2018; 9:1310.

53. Krieg C, Nowicka M, Guglietta S, Schindler S, Hartmann FJ, Weber LM. High-dimensional single-cell analysis predicts response to anti-PD-1 immunotherapy. Nat Med. 2018; 24:144-53.

54. Xu-Monette Z, Zhang M, Li J, Young K. PD-1/PD-L1 Blockade: Have we found the key to unleash the antitumor immune response? Front Immunol. 2017; 8:1597.

55. Song M, Chen X, Wang L, Zhang Y. Future of anti-PD-1/ PD-L1 applications: Combinations with other therapeutic regimens. Chin J Cancer Res. 2018; 30(2):157-172.
56. Dong H, Strome SE, Salomao DR, Tamura H, Hirano F, Files DB, Roche PC, Lu J, Zhu G, Tamada K, Lennon VA, Celis E, Chen L. Tumor-associated B7-H1 promotes T-cell apoptosis: a potential mechanism of immune evasion. Nat Med. 2002; 8(8):793-800.

57. Spranger S, Spaapen RM, Zha Y, Williams J, Meng Y, Ha TT, Gajewski TF. Up-regulation of PD-L1, IDO, and T(regs) in the melanoma tumor microenvironment is driven by CD8(+) T cells. Sci Transl Med. 2013; 5(200):200ra116.

58. Taube JM, Anders RA, Young GD, Xu H, Sharma R, McMiller TL, Chen S, Klein AP, Pardoll DM, Topalian SL, Chen L. Colocalization of inflammatory response with B7-h1 expression in human melanocytic lesions supports an adaptive resistance mechanism of immune escape. Sci Transl Med. 2012. 4(127):127ra37.

59. Chen L, Han X. Anti-PD-1/PD-L1 therapy of human cancer: past, present, and future. J Clin Invest. 2015; 125(9):3384-3391.

60. Shen X, Zhao B. Efficacy of PD-1 or PD-L1 inhibitors and PD-L1 expression status in cancer: meta-analysis. BMJ. 2018; 262:k3529.

61. Parsa AT, Waldron JS, Paanner A, Crane CA, Parney CA, Barry JJ, Cachola KE, Murray JC, Tihan T, Jensen MC, Mischel PS, Stokoe D, Pieper RO. Loss of tumor suppressor PTEN function increases B7-H1 expression and immunoresistance in glioma. Nat Med. 2007; 13(1):84-88.

62. Velcheti V, Schalper KA, Carvajal DE, Anagnostou VK, Syrigos KN, Sznol M, Herbst RS, Gettinger SN, Chen L, Rimm DL. Programmed death ligand-1 expression in nonsmall cell lung cancer. Lab Invest. 2014; 94(1):107-116.

63. Khagi Y, Kurzrock R, Patel SP. Next generation predictive biomarkers for immune checkpoint inhibition. Cancer Metastasis Rev. 2017; 36(1):179-190. doi: 10.1007/s10555-0169652-y.

64. Wong RM, Scotland RR, Lau RL, Wang C, Korman AJ, Kast WM, Weber JS. Programmed death-1 blockade enhances expansion and functional capacity of human melanoma antigen-specific CTLs. Int Immunol. 2007; 19:1223-1234.

65. Ahmadzadeh M, Johnson LA, Heemskerk B, Wunderlich JR, Dudley ME, White DE, Rosenberg SA. Tumor antigen-specific CD8 T cells infiltrating the tumor express high levels of PD-1 and are functionally impaired. Blood. 2009; 114(8):1537-1544.

66. Egelston CA, Avalos C, Tu TY, Simons DL, Jimenez G, Jung JY, Melstrom L, Margolin K, Yim JH, Kruper L, Mortimer J, Lee PP. Human breast tumor-infiltrating CD8+ T cells retain polyfunctionality despite PD-1 expression. Nat Commun. 2018; 9(1):4297.

67. Schnorfeil FM, Lichtenegger FS, Emmerig K. T cells are functionally not impaired in AML: increased PD-1 expression is only seen at time of relapse and correlates with a shift towards the memory $\mathrm{T}$ cell compartment [serial online]. J Hematol Oncol. 2015; 8:93. 


\title{
Рецептор PD-1 на иммунных клетках, его экспрессия и потенциальная роль в противоопухолевой терапии
}

\author{
Дмитрий С. Елезов ${ }^{1}$, Игорь В. Кудрявцев ${ }^{2,3,4}$ \\ ${ }^{1}$ НИИ детской онкологии, гематологии и трансплантологии им. Р. М.Горбачевой, Первый Санкт-Петербургский \\ государственный медицинский университет им. И. П. Павлова, Санкт-Петербург, Россия \\ ${ }^{2}$ Отдел иммунологии, Институт экспериментальной медицины, Санкт-Петербург, Россия \\ ${ }^{3}$ Отдел онкоиммунологии, Национальный медицинский научно-исследовательский центр онкологии им. Н. Н. Петрова, \\ Санкт-Петербург, Россия \\ ${ }^{4}$ Отдел фундаментальной медицины, Дальневосточный федеральный университет, Владивосток, Россия
}

\section{Резюме}

B последнее десятилетие к PD-1 и его лиганду PDL1 приковано большое внимание в связи с высокой эффективностью терапии ряда опухолевых заболеваний блокаторами PD-1/PD-L1. B рамках данного обзора обобщены данные по экспрессии рецептора PD-1 на различных популяциях T-клеток и его потенциальной роли в противоопухолевом иммунном ответе.

Кроме общего описания молекулярной структуры и межмолекулярных взаимодействий, основное внимание в обзоре уделено особенностям экспрессии PD-1 на популяции CD8+ T-клеток, которая играет центральную роль в противоопухолевом иммунном ответе. Общие закономерности изменений уровня экспрессии PD-1 в ходе процессов клеточной активации и дифференцировки были рассмотрены в основном относительно этой клеточной популяции. Экспрессия PD-1 отмечается также на поверхности T-регуляторных, NK-, инвариантных NKT-, миелоидных супрессорных клеток, что, вероятно, имеет важную роль в ходе противоопухолевого иммунного ответа, и имело отражение в данном обзоре.
При проведении терапии ингибиторами PD-1/PD-L1 вышеперечисленные популяции могут влиять на формировании резистентности к данному виду терапии. В связи с этим, многие современные исследования направлены на выяснение их вовлеченности в процесс иммунорегуляции и возможности использования их в качестве биомаркеров оценки эффективности терапии ингибиторами иммунных контрольных точек.

\section{Ключевые слова}

PD-1, PD-L1, экспрессия, Т-клетки, противоопухолевая терапия, ингибиторы иммунных контрольных точек. 